\title{
Sequential Expression of Trks A, B, and C in the Regenerating Olfactory Neuroepithelium
}

\author{
A. Jane I. Roskams, ${ }^{1}$ M. Angelyn Bethel, ${ }^{1}$ K. Joseph Hurt, ${ }^{1}$ and Gabriele V. Ronnett ${ }^{2}$ \\ Departments of ${ }^{1}$ Neuroscience and ${ }^{2}$ Neurology, The Johns Hopkins School of Medicine, Baltimore, Maryland 21205
}

This study examines how the family of neurotrophin receptor tyrosine kinases (Trks) participates in the regeneration and replacement of olfactory neurons within the adult rat olfactory neuroepithelium. mRNA and protein products representing the high-affinity nerve growth factor (NGF) receptor Trk A, its family members Trk $B$ and Trk $C$, and the low-affinity NGF receptor (INGFR) are all detected within both mature and regenerating olfactory neuroepithelium and within primary cultures of olfactory neurons. Cellular immunoreactivity for Trks $A, B$, and $C$ and INGFR changes dramatically during the lifetime of an olfactory neuron and is demonstrated by inducing the epithelium into a coordinate rapid cycle of degeneration and regeneration in vivo by removal of the target organ, the olfactory bulb. Trk A-positive neuronal precursor basal cells undergo mitosis to produce Trk B-positive immature neurons that mature under the local influence of the olfactory neuroepithelium and the target-derived influence of the olfactory bulb to become a Trk C-positive mature neuron. Primary cultures of immature olfactory neurons demonstrate neurotrophin-induced phosphorylation of Trks $A, B$, and $C$ and subsequent activation of the immediate early gene c-Fos, and they change their expression of differentiation stage-specific markers after treatment with individual and combinations of neurotrophins. This is the first population of neurons of a single lineage in which Trks $A, B$, and $C$ and the INGFR have been demonstrated to be expressed sequentially during neuronal division, commitment, and differentiation and to be fully capable of transducing cellular signals causing phenotypic changes in differentiation state.

Key words: olfactory receptor neurons; regeneration; neurotrophins; Trk receptors; neurogenesis; degeneration
The trophic interactions of the neurotrophin family of growth factors nerve growth factor (NGF), brain-derived neurotrophic factor (BDNF), neurotrophin-3 (NT-3), and neurotrophin-4 and -5 (NT-4/5) have been described extensively (Eide et al., 1993; Glass and Yancopoulos, 1993; Lindsay et al., 1994). NGF has been characterized as a survival and differentiation factor for neurons (Thoenen, 1991), and the cloning and expression of BDNF (Leibrock et al., 1989), NT-3 (Ernfors et al., 1990; Hohn et al., 1990; Jones and Reichardt, 1990; Maisonpierre et al., 1990; Rosenthal et al., 1990), and NT-4/5 (Berkemeirer et al., 1991; Hallbook et al., 1991; Ip et al., 1992) have elucidated further a function for this family in neuronal transformation, morphogenesis, and differentiation. A family of receptor tyrosine kinasesTrks A, B, and C-has been cloned recently and identified as having multiple interactions with this fanily of growth factors. NGF is the preferred ligand for Trk A (Cordon-Caro et al., 1991; Kaplan et al., 1991; Klein et al., 1991a), NT-3 is the preferred ligand for Trk C (Hohn et al., 1990; Lamballe et al., 1991; Soppet et al., 1991; Ip et al., 1993a), and Trk B can preferentially bind

\footnotetext{
Received June 30, 1995; revised Sept. 26, 1995; accepted Nov. 15, 1995.

This work was supported by U.S. Public Health Service Grant F32 DC00121-02 to A.J.R., a McKnight Scholars Award to G.V.R., and grants from the Whitehall Foundation, International Flavors and Fragrances, and U.S. Public Health Service Grant 1RO1-DC01704-01 to G.V.R. We acknowledge the excellent technical assistance of Lara Davidovich, Joel Sklar, and Parham Jaberi, and the monumental computer-troubleshooting efforts of Dr. Clark Riley. We thank Luis Parada and Dan Soppet for their initial gift of anti-Trk B and $-\mathrm{C}$ antibodies, and we thank George Yancopoulos and his Discovery Group at Regeneron Pharmaceuticals for their generous gift of neurotrophins and anti-Trk probes, and for their very helpful interaction and encouragement. We also thank Mairano Barbacid and George Yancopoulos for careful review and discussion of this manuscript.

Correspondence should be addressed to Dr. Gabriele V. Ronnett, Department of Neuroscience, The Johns Hopkins University School of Medicine, 725 North Wolfe Street, Baltimore, MD 21205.

Copyright (C) 1996 Society for Neuroscience $0270-6474 / 96 / 161294-14 \$ 05.00 / 0$
}

either BDNF or NT-4/5 depending on the cell system in which it is expressed (Glass et al., 1991; Soppet et al., 1991; Ip et al., 1992, 1993). However, the redundancy of this family is demonstrated by the fact that Trks A and B also display a lower affinity for NT-3 (Cordon-Cardo et al., 1991; Glass et al., 1991; Soppet et al., 1991; Ip et al., 1993). An additional receptor, the low-affinity NGF receptor (INGFR; p75) also has been cloned and identified, which will bind each of the neurotrophins with a similar low affinity of 1 $\times 10^{-9} \mathrm{M}$ (Radeke et al., 1987; Meakin and Shooter, 1992; Barbacid, 1993a).

The olfactory neuroepithelium, situated within the nasal cavity, is an excellent model for studying neuronal differentiation in vivo because of its ability to constantly regenerate neurons during the lifetime of animals, including rat and human (Graziadei, 1971; Moulton, 1974; Graziadei and Monti-Graziadei, 1979a,b; Suzuki and Takeda, 1993). In the rat, each olfactory receptor neuron (ORN) degenerates every 4-6 weeks and is replaced by a newly differentiated precursor neuron that assumes a mature state within the upper layers of the olfactory neuroepithelium and projects afferent axons directly back into the olfactory bulb (Farbman, 1990).

The normal olfactory neuroepithelium displays a topographical pattern of neuronal maturity, in which a neuronal precursor population of basal cells is situated at the base of the epithelium (Vollrath et al., 1985; Calof and Chikaraishi, 1989; Schwartz Levy et al., 1991). Immature neurons that express growth-associated protein-43 (GAP-43) and L1 are developmentally low in the epithelium (Verhaagen et al., 1989). Both immature and mature neurons (and globose basal cells) express neural-cell adhesion molecule (N-CAM) (Miragall et al., 1988; Key and Akeson, 1990), and the center of the epithelium is filled with olfactory marker protein (OMP)-positive mature neurons (Margolis, 1985; Farb- 
man and Margolis, 1980). The top layer of the epithelium contains sustentacular (supporting) cells and degenerating neurons (Graziadei and Monti-Graziadei, 1979a,b; Farbman and Squinto, 1985). The olfactory neuroepithelium also can be induced into a state of coordinate regeneration by removal of the target organ, the olfactory bulb. In the absence of trophic support from the olfactory bulb, olfactory neurons cannot fully mature and will be replaced continually by the induction of basal cell division (Schwartz Levy et al., 1991; Carr and Farbman, 1992).

In this study, Trks A, B, and C are all detected in the olfactory neuroepithelium by PCR, immunoblot, and immunohistochemical analysis. Trk A immunoreactivity (IR) is found in sparse populations of basal cells in normal neuroepithelium, and Trk A IR becomes intense and widespread after bulbectomy, eventually encompassing the entire basal cell layer. Trk B IR is detected in cell bodies and dendrites of immature neurons after mitotic division into daughter neuroblasts, but shifts as olfactory neurons mature to stain heavily the afferent axons of ORNs projecting to the olfactory bulb, the prevalent pattern observed in mature olfactory neuroepithelium. Trk C IR appears only in the membrane of mature populations of ORNs and lightly in axon bundles. There is intense expression of INGFR in glomeruli where ORNs synapse with mitral cells in the olfactory bulb. Expression of INGFR and NGF also is found in the cell bodies of degenerating neurons. Trks A, B, and $\mathrm{C}$ each become phosphorylated when primary cultures of olfactory neurons are challenged with their preferred high-affinity neurotrophin ligand and induce downstream activation of c-Fos expression, causing long-term changes in expression of the neuronal markers N-CAM and GAP-43.

\section{MATERIALS AND METHODS}

Bulbectomy procedure. Adult Sprague-Dawley rats were anesthetized with Xylaket $[25 \%$ ketamine $\mathrm{HCl}, 100 \mathrm{mg} / \mathrm{ml} ; 2.5 \%$ Xylazine, $100 \mathrm{mg} / \mathrm{ml}$ (A. J. Buck, Owings Mills, MD), $14.2 \%$ ethanol in $0.9 \%$ saline] and fixed in a stereotaxic apparatus during surgery. For unilateral bulbectomies, the right olfactory bulb was exposed via a partial dorsal craniotomy and was ablated by suction. Care was taken to avoid damage to the contralateral (left) olfactory bulb. Bilateral bulbectomy was performed by also suctioning the left olfactory bulb. The ablation cavity was filled with gelfoam to prevent invasion of frontal cortex into this cavity that could provide an alternative target for regenerating olfactory axons. The skin above the lesion then was sutured, and animals were allowed to rccover from anesthesia under a heat lamp. The degree of lesion was verified visually and microscopically. In all cases reported, it was complete or supercomplete (extending into the olfactory peduncle). After recovery from anesthesia, rats were returned to the animal colony and maintained on a normal diet until killing at $3 \mathrm{~d}$ and 1,2 , and 3 weeks after bulbectomy.

$R N A$ preparation and Northern blotting. Animals were killed by decapitation after lethal anesthesia, and olfactory tissue was removed and frozen immediately in liquid nitrogen and stored at $-80^{\circ} \mathrm{C}$ until sufficient tissue was collected for RNA purification. Primary cultures of olfactory neurons were treated with the appropriate growth factor or inhibitor, washed briefly with ice-cold PBS, and frozen on liquid nitrogen until ready for RNA purification. RNA was prepared according to established protocols by homogenizing dissected olfactory tissue in guanidinium isothiocyanatc and pelleting RNA through a cesium chloridc gradient while centrifuging for $20-22 \mathrm{hr}$ at $35,000 \mathrm{rpm}$. Integrity and quantity of RNA were assessed by absorbance at $260 / 280 \mathrm{~nm}$ and agarose gel electrophoresis. RNA $(10 \mu \mathrm{g})$ from each experimental sample was separated by formaldehyde gel-agarose electrophoresis on a $1.0 \%$ agarose gel. RNA was then transferred to Genescreen Plus membranes (DuPont NEN, Boston, MA) by capillary action. Blotted membranes were baked for $2 \mathrm{hr}$ before hybridization. c-Fos probes were generated by random prime labeling (Boehringer Mannheim, Indianapolis, IN) of a $2 \mathrm{~kb}$ gel-purified fragment of the open reading frame of c-Fos. Inserts from plasmids encoding Trks A, B, and C (gift from G. Yancopoulos, Regeneron Pharmaceuticals, Tarrytown, NJ) were random prime-labeled by the same method. Hybridization was performed using KwikHyb (Stratagene, La Jolla, CA) at high stringency $\left(65^{\circ} \mathrm{C}\right)$. Blots were visualized by exposure to a PhosphorImager screen (Molecular Dynamics, Sunnyvale, $\mathrm{C} \Lambda$ ) for $12 \mathrm{hr}$. Equal loading of lanes was confirmed by intensity of the $18 \mathrm{~s}$ ribosomal band, identified using an anti-18s oligonucleotide (Roskams et al., 1993).

Reverse transcription-PCR amplification of Trk transcripts. RNA was prepared from normal rat olfactory neuroepithelium, olfactory bulb, and primary cultures of olfactory neurons. RNA $(10 \mu \mathrm{g})$ from each source was reverse-transcribed (Superscript RT, Gibco, Gaithersburg, MD) using oligo(dT) primers (Promega, Madison, WI), and control reactions, using olfactory epithelium RNA, were preincubated for $15 \mathrm{~min}$ with RNase A before the reverse-transcription (RT) reaction. PCR was performed on a one-tenth aliquot of the $\mathrm{RT}$ reaction mixture for 35 cycles at $94^{\circ} \mathrm{C}$ for 30 sec, $50^{\circ} \mathrm{C}$ for $1 \mathrm{~min}$, and $72^{\circ} \mathrm{C}$ for $2 \mathrm{~min}$ using $\mathrm{Taq}$ DNA polymerase (Stratagene). Primers were designed to be specific to unique regions of Trks A, B, and C and NGFR (i.e., regions that displayed no overlapping homology with other members of the neurotrophin receptor family):

Trk A: 5'-ACCTGACGGAGCTCTATG, 3'-GCTCTGTGAGGATCCAGTCAG;

Trk A-2: 5'-GACTTCGTTGATGCTGGCTTG, 3'-TGCCCAGCACGTCACATT;

Trk B: 5'-CACCACTAGGATTTGGTGTAC, 3'-CTCCGTTGTAGAACCACTGAA;

Trk C: 5'-ATGGATGTCTCTCTTTGCCCA; 3'-GCAGTCCAGTGACGATGCAGG;

NGFR: 5'-CAAGGAGACATGTTCCACAGG; 3'-CAGAGATGCCACTGTCGCTGT

Because of the heterogeneity of the established members of this family, all PCR products of the correct size were subcloned into the TA vector (Invitrogen, San Diego, CA) and sequenced along their entire length to confirm identity of transcripts.

Immunoblot analysis. Soluble homogenates from experimental samples were prepared in buffer containing $25 \mathrm{~mm}$ Tris- $\mathrm{HCl}, \mathrm{pH} 7.4$, with $1 \mathrm{~mm}$ EDTA and $0.1 \%$ Triton X-100, and assayed for protein using the BCA. protein assay kit (Pierce, Rockford, IL). Proteins were separated on a $5-12 \%$ SDS polyacrylamide gradient gel (50 $\mu \mathrm{g}$ protein/lane) and transferred to nitrocellulose for $2 \mathrm{hr}$ at $300 \mathrm{~mA}$ (Bio-Rad, Hercules, CA). Blots were blocked for $1 \mathrm{hr}$ at room temperature in 5\% BM-block (Boehringer Mannheim) in Tris-buffered saline and then probed with affinity-purified antiserum overnight at $4^{\circ} \mathrm{C}$, followed by a secondary antibody incubation for $1 \mathrm{~h} / \mathrm{r}$ at room temperature with a horseradish peroxidase-linked goat anti-rabbit secondary antibody (Boehringer Mannheim) for $1 \mathrm{hr}$ at room temperature. Affinity-purified polyclonal antisera to Trk A (Oncogene Scientific, Uniondale, NY), Trk B, truncated Trk B, and Trk C (Santa Cruz Biotech, Santa Cruz, CA) were used at 1:250 dilution. The two Trk $B$ antibodies were made against a peptide that arises in the external domain of Trk B (which recognizes all forms of Trk B) and the 15-amino-acid insert that is unique only to the fully truncated form of Trk B (Trk B, TK-). Bands were visualized using the enhanced chemiluminescence (ECL; Amersham) reagents. Western blots also were performed using antiserum preabsorbed with a 10 -fold excess of pcptide before primary antibody incubation.

Immunohistochemistry. Adult Sprague-Dawley rats were anesthetized with Xylaket and perfused with saline, followed by $4 \%$ freshly depolymerized $p$-formaldehyde in $0.1 \mathrm{M}$ PBS. The offactory tissue was then dissected and post-fixed in $4 \% p$-formaldehyde in PBS for $2 \mathrm{hr}$. After fixation, all tissue was sequentially bathed in 10,20 , and $30 \%$ sucrose in PBS for cryoprotection, transferred to plastic molds, and embedded in OCT medium (Tissue-Tek, Baxter, Columbia, MD) on dry ice. Cryostat sections $(12 \mu \mathrm{m})$ were cut on gelatin-coated glass slides and dried overnight. Sections were blocked for $1 \mathrm{hr}$ in PBS containing 1\% normal goat serum and then incubated overnight at $4{ }^{\circ} \mathrm{C}$ in the same buffer containing affinity purified (1:100) antisera to Trks $\Lambda, B$, and $C$ and truncated Trk B. To immunostain for the INGFR and NGF, we used monoclonal antibodies (Boehringer Mannheim) with sections blocked in normal rabbit serum. The anti-NGF antibody has been tested extensively for cross-IR with BDNF and NT-3, and no evidence has been found to suggest that cross-reactivity with other neurotrophins (Boehringer Mannheim) is a concern. Primary antibodies were recognized and immunohistochemistry was performed using an avidin-biotin-peroxidase kit (Elite kit, Vectastain, Vector Laboratories, Burlingame, CA) and visualized with diaminobenzidine. Double-immunofluorescence was performed using a primary goat anti-rat OMP antibody (gift from Frank Margolis, Department of Anatomy, University of Maryland School of Medicine) and the mouse anti-NGFR monoclonal antibody (Boehringer Mannheim). 
Figure 1. Trks $\mathrm{A}, \mathrm{B}$, and $\mathrm{C}$ and INGFR expression in olfactory neurons. $A$, RNA prepared from olfactory tissue, olfactory bulb, and primary cultures of olfactory neurons was reversetranscribed and, subsequently, products were amplified from this template using primers specifically designed against conserved regions of $\operatorname{Trks} A, B$, and $C$ and $I N G F R$. Control lanes contained RNA and primers for PCR, but reverse transcriptase was omitted. Transcripts for INGFR and Trks A, B, and $\mathrm{C}$ are detected in RNA prepared from olfactory neuroepithelium and olfactory neuron primary cultures. Trk A was not detected in RNA prepared from olfactory bulb. $B$, Soluble protein extracts $(50 \mu \mathrm{g})$ prepared from adult olfactory tissue were separated by PAGE on $5-12 \%$ gradient gels and transferred to nitrocellulose. Blots then were probed with anti-Trk A (Oncogene Science), Trk B, Trk B (TK-), and Trk $\mathrm{C}$ antibodies (Santa Cruz Biotech) and developed using the ECL technique. Immunoblots revealed the presence of full-length $(F L)$ transcripts for Trks $\mathrm{A}, \mathrm{B}$, and $\mathrm{C}$ and truncated forms (Trunc) or Trks B and C.

I

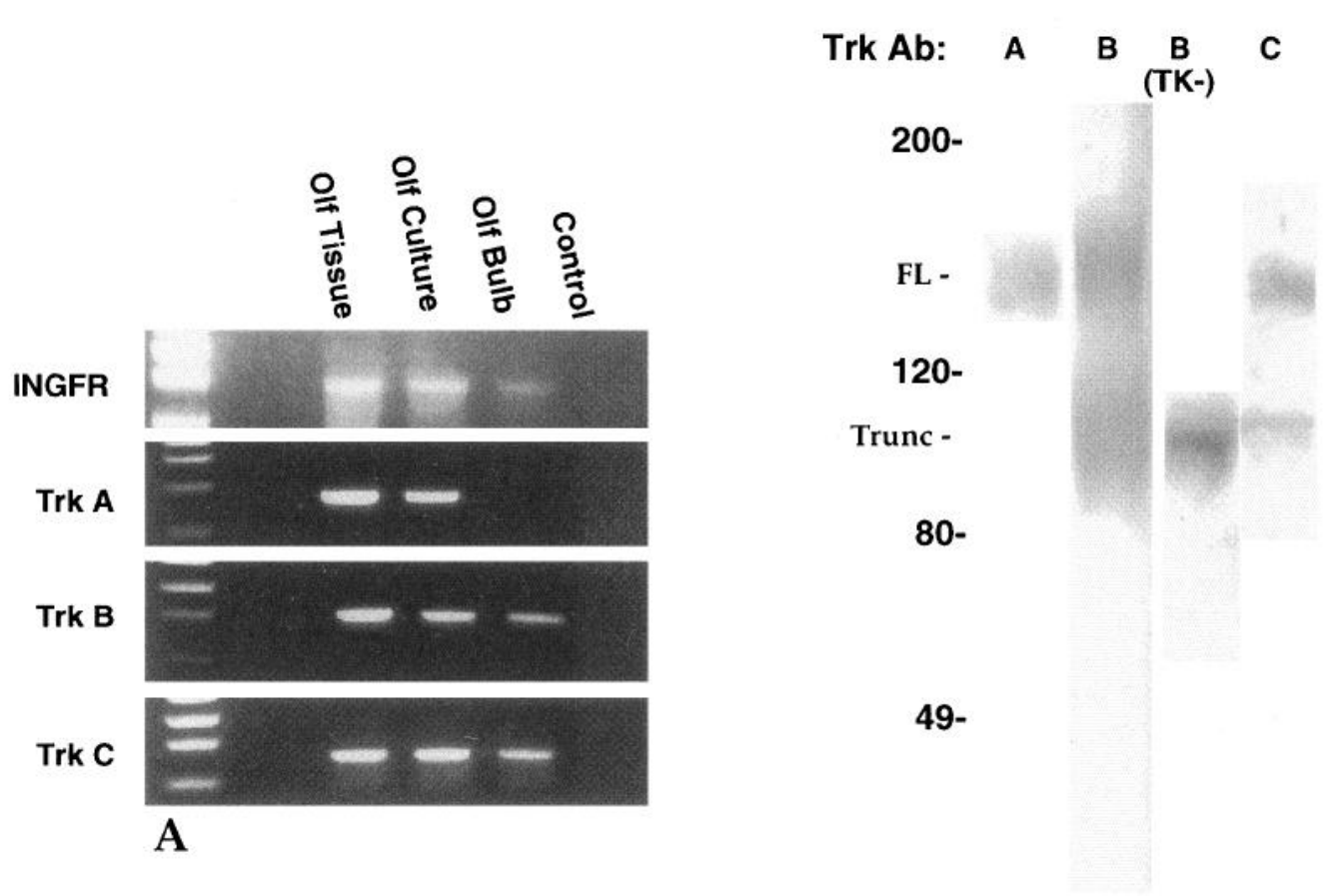

B
Growth factor treatment of olfactory neurons. Primary cultures of olfactory neurons were prepared as described previously (Ronnett et al., 1991), except that neurons were prepared from rats 1-2 d of age, plated at $0.25-0.5$ times the density previously reported, and media was not supplemented with cytosine arabinoside and NGF. Cultures were allowed to mature for 48-72 hr in MEM-DVal (Gibco) supplemented with $15 \%$ dialyzed fetal bovine serum (HyClone, Logan, UT). The modification in culture conditions was used because it has been more successful in producing cultures with a greater number of neurons at different stages of differentiation. For biochemical and molecular analysis, medium then was removed and replaced with MEM-DVal alone for $24 \mathrm{hr}$ to prepare the neurons for growth factor treatment. NGF, BDNF, NT-3, and NT-4 then were added at $50 \mathrm{ng} / \mathrm{ml}$ MEM-DVal for $10 \mathrm{~min}$ (for phosphorylation of Trks) and $40 \mathrm{~min}$ (for c-Fos induction) before being washed with PBS and processed for analysis. Control experiments were performed when the neurotrophins were added in the presence of $100 \mathrm{nM} \mathrm{K252a}$ (Calbiochem, La Jolla, CA) (Berg et al., 1992).

Immunohistochemical analysis of primary neuron cultures. Cells were prepared as described above and plated in MEM-DVal with dialyzed 15\% fetal calf serum (FCS) on laminin-coated, two-chambered slides for $24 \mathrm{hr}$. Media then was removed and replaced with MEM-DVal containing $10 \%$ FCS alone or supplemented with NGF, BDNF, NT-3, and NT-4, individually and in combination, as indicated. After an additional $3 \mathrm{~d}$ in culture, cells were washed several times and fixed in $4 \% p$-formaldehyde before staining with rabbit anti-cytokeratin (1:500; Dakopatts, Glostrup, Denmark), monoclonal anti-N-CAM (1:500; Becton Dickinson, Mountain View, CA), monoclonal anti-GAP-43 (1:500; Boehringer Mannheim), polyclonal anti-L1 (1:100; Boehringer Mannheim), polyclonal anti-Trk A (1:100; Oncogene Sciences and Collaborative Research, Bedford, MA), polyclonal anti-Trk B (1:50; Santa Cruz Biotech and Transduction Labs, Lexington, KY), polyclonal anti-Trk C (1:50; Santa Cruz Biotech), monoclonal anti-INGFR (p75), and anti-NGF (1:50; Boehringer Mannheim). Primary antibodies were detected using the appropriate Elite Vectastain kit and visualized using AEC as chromogen (Biomeda, Fullerton, CA). Cell counts were performed by counting 5 frames/well, visualized through a $20 \times$ objective on a Zeiss Axiophot microscope (Thornwood, NY), and analyzed for statistical significance using a Student's $t$ test. Cells were counted as N-CAM-positive if distinct cell body staining was identified. GAP-43 staining was assessed by counting both cell body and neurite staining within a given frame. Each experiment was performed in triplicate within a given week to allow for intra-assay variability, and each experiment was performed on at least three different occasions to account for interassay variability. The data shown are the analysis of one series of experiments performed in triplicate and are typical of the profiles obtained from additional experiments.

Immunoprecipitation and detection of Trks and phosphotyrosine proteins. Cells were lysed, and each well of a 6-well plate (Nunc, Naperville, IL) was resuspended in $1 \mathrm{ml}$ of modified RIPA buffer (PBS, 1 mM EDTA, $0.2 \%$ SDS, $1 \%$ Nonidet P- 40 , and $0.5 \%$ sodium deoxycholate) containing the protease inhibitors leupeptin, antipain, chymostatin, pepstatin (Peninsula Labs, Belmont, CA), and benzamide (Sigma, St. Louis, MO) and immediately aliquoted and frozen. Anti-Trk A, - B, and -C affinity-purified polyclonal or polyclonal anti-phosphotyrosine (Transduction Labs) was added to a concentration of $2 \mathrm{mg} / \mathrm{ml}$ (Trks) or $5 \mathrm{mg} / \mathrm{ml}$ (antiphosphotyrosine) and incubated for $1.5 \mathrm{hr}$ at $4^{\circ} \mathrm{C}$. SDS-washed Pansorbin (Calbiochem) then was added to 1:20 (v/v) and incubated for $2 \mathrm{hr}$ before centrifugation and washing ( 3 times with $1 \times$ RIPA). Pellets were resuspended in SDS-PAGE loading buffer and separated on 5-12\% polyacrylamide gels before transfer to nitrocellulose membrane. Trk immunoprecipitates then were blotted using the monoclonal anti-phosphotyrosine (4G10) antibody (Upstate Biotechnology, Lake Placid, NY). Phosphotyrosine immunoprecipitates were immunoblotted as above with the antiTrk antibody specific to the neurotrophin ligand used. Trk immunoprecipitates were incubated for $1 \mathrm{hr}$ at room temperature, with a subsequent secondary antibody incubation for $2 \mathrm{hr}$ at room temperature. Blots were visualized using ECL, as described above, and images were processed using an AGFA image scanner (AGFA, Wilmington, MA).

\section{RESULTS}

\section{Trks A, B, and C and the INGFR are expressed in olfactory neurons in vivo and in vitro}

To identify which Trk family members are present in olfactory tissues, we performed RT reactions on RNA prepared from olfactory neuroepithelium, primary cultures of olfactory neurons and olfactory bulb, followed by PCR of cDNA-utilizing primers specific to the INGFR and Trks A, B, and C. Transcripts corresponding to the mRNA for the INGFR and Trks A, B, and C were all detected in olfactory tissue and primary olfactory neuronal cultures, but not in reactions in which we omitted reverse tran- 
scriptase (Fig. 1A, column -). To detect Trk A, a nested modification of the PCR technique was applied, suggesting that it may be less abundant then the other growth factor receptors. PCR products of the appropriate sizes for Trks B and C, but not Trk A, also were detected in olfactory bulb. The pattern of 1NGFR and Trk expression in the olfactory bulb is in accord with previous reports (Barbacid, 1993b).

We also performed immunoblot analysis for Trks A, B, and C on soluble protein prepared from olfactory tissue (Fig. $1 B$ ). For detection of Trk B, truncatcd Trk B, and Trk C, immunoblots were performed using two sets of polyclonal antibodies. Anti-Trk B, Trk B (TK-), and anti-Trk C antisera [gifts from L. Parada and D. Soppet (National Cancer Institute, Frederick, MD), designated 442 , 444, and 510, respectively] were used to produce immunoblots that were used as a template with which to compare the immunoblots of commercially available antibodies directed against the Trk-receptor kinases Trk B and Trk C (Santa Cruz Biotech; Fig. 1B). For TK - detection, immunoprecipitations first were performed using the donated polyclonal TK - antibody, and then immunoprecipitates were blotted using the second anti-TKantibody (Santa Cruz Biotech) (Fig. 1 $B$ ). Two different commercially available anti-Trk $A$ antisera were used that gave the same pattern on immunoblot and immunohistochemical analysis (Oncogene Sciences and Collaborative Research; Fig. 1B). Therefore, the identical Western blot pattern was obtained using at least two different antibodics for cach Trk reccptor. Immunoblots in Figurc $1 B$ were all performed with the same commercially available antibody that was used subsequently for immunohistochemical localization, and both immunoblot and staining patterns were blocked successfully by preincubation of antibody with an excess of immunizing peptide (data not shown). Because the Western blot pattern for each antibody is slightly different and there is little or no overlap in the immunocytochemical patterns of expression observed for Trks A, B, and C, we can conclude that the antibodies, in fact, are recognizing different Trks (Fig. 2).

Immunoblot analysis reveals that Trk $\mathrm{A}$ is present as a single band at $130-140 \mathrm{kDa}$. Trk B is present in two forms-130-145 and $\sim 90 \mathrm{kDa}$. Correspondingly, TK - is clearly present at $90 \mathrm{kDa}$. We detect two major sizes of Trk C protein-a full-length, 145 $\mathrm{kDa}$ and one truncated $(\sim 90 \mathrm{kDa})$ version in our neurons, in accord with previous reports of different splice variants of Trk C (Valenzuela et al., 1993), although faint bands of intervening sizes also were detected when higher concentrations of antibody were used. The thickness of the $130-150 \mathrm{kDa}$ bands observed is attributed to the fact that they are modified post-translationally and heavily glycosylated.

Although we are able to demonstrate the presence of all three members of the Trk family of receptors in olfactory neuroepithelial tissue and olfactory neurons, the information oblained by PCR and immunoblot analysis is not sufficient to demonstrate whether these receptors are positioned suitably within the cell to function as growth factor receptors. Therefore, we have examined the immunohistochemical distribution of each of the Trk family members in sections of normal olfactory tissue, bulbectomized olfactory tissue, and primary cultures of olfactory neurons.

\section{Trks A, B, and C are expressed in different neuronal subpopulations throughout the olfactory neuroepithelium}

Trk A expression is detected only in rare groups of precursor neuron basal cells at the base of the adult neuroepithelium (Fig. $2 A)$. Trk $\mathrm{B}$ is expressed in the cell bodies and dendrites of immature receptor neurons (IRN) and the primary afferent projections of mature olfactory neurons projecting back to the olfactory bulb (Fig. $2 B$ ). The major truncated form of Trk B (TK-) has a much more limited distribution in the olfactory neuroepithelium (Fig. 2D), where IR is found faintly in axon bundles of primary afferents, possibly contributing to the axonal IR seen with the pan-Trk B antibody (Fig. 2B). Intense areas of Trk B (TK-) IR also are observed occasionally in small "uvoid" cells high in the epithelium, which resemble degenerating neurons.

Trk C clearly is not expressed in basal cells or sustentacular cells, but a "trabecular" pattern of IR is detected at low levels throughout the outer membranes of all mature olfactory neurons lying in the middle third of the epithelium. The primary afferent axon bundles also are faintly immunoreactive for Trk $\mathrm{C}$ (Fig. $2 \mathrm{C}$ ).

\section{NGF and the INGFR do not colocalize with Trk receptors}

IR for the INGFR (p75) is confined to the lamina propria in normal neuroepithelium. This IR is streaky in appearance and is particularly intense around blood vessels coursing through the lamina propria (Fig. $2 E$ ). The streaky staining pattern observed is identical to that for glial fibrillary acidic protein in Schwann cells of the olfactory nerve (Barber and Lindsay, 1982; Pixley, 1992), suggesting that the INGFR actually is being expressed not in neurons, but on glial cells in the lamina propria, in accord with recently published observations (Gong et al., 1994).

Coincident NGF expression cannot be detected within the normal olfactory neuroepithelium by immunocytochemical techniques that are capable of detecting NGF IR in other regions of the central and peripheral nervous systems, such as the olfactory bulb (Fig. 2F).

\section{The NGF receptor is expressed where mature ORNs synapse}

The INGFR cannot be detected within the neurons of the mature olfactory neuroepithelium (Fig. $2 E$ ). The mRNA for INGFR is detectable, however, in primary cultures of olfactory neurons by PCR (Fig. 1A). INGFR IR is clearly detected in a glomerular pattern in the external layer of the olfactory bulb, where the nerve terminals of mature olfactory neurons synapse, and also very faintly in the axons of ORNs entering the olfactory bulb (Fig. $3 A, B)$. This suggested expression of INGFR at synaptic terminals of ORNs is suggested further by a close overlap in expression with the OMP within individual glomeruli of the olfactory bulb (Fig. $3 C, D$ ).

The spatial distribution of the immunoreactive pattern for Trk expression suggests that olfactory neurons change in their neurotrophin responsiveness at different stages of olfactory neuron development and that the Trk receptors in olfactory neurons likely are working independently of the INGFR. To determine whether this spatial pattern is coordinated temporally during neurogenesis, we performed a series of experiments to synchronize the regeneration of the neuroepithelium by performing a unilateral bulbectomy on adult rats and monitoring the stages of recovery of the ipsilateral neuroepithelium.

\section{Trk A, NGF, and INGFR do not colocalize in regenerating olfactory neurons}

Trk A expression is induced rapidly after bulbectomy, and strong IR is detected in patches of basal cells as early as $3 \mathrm{~d}$ after bulbectomy (Fig. 4B). Additional groups of Trk-A-positive basal cells are recruited as the neuroepithelium is allowed to recover for 1 and 2 weeks after bulbectomy, at which time the entire basal cell 

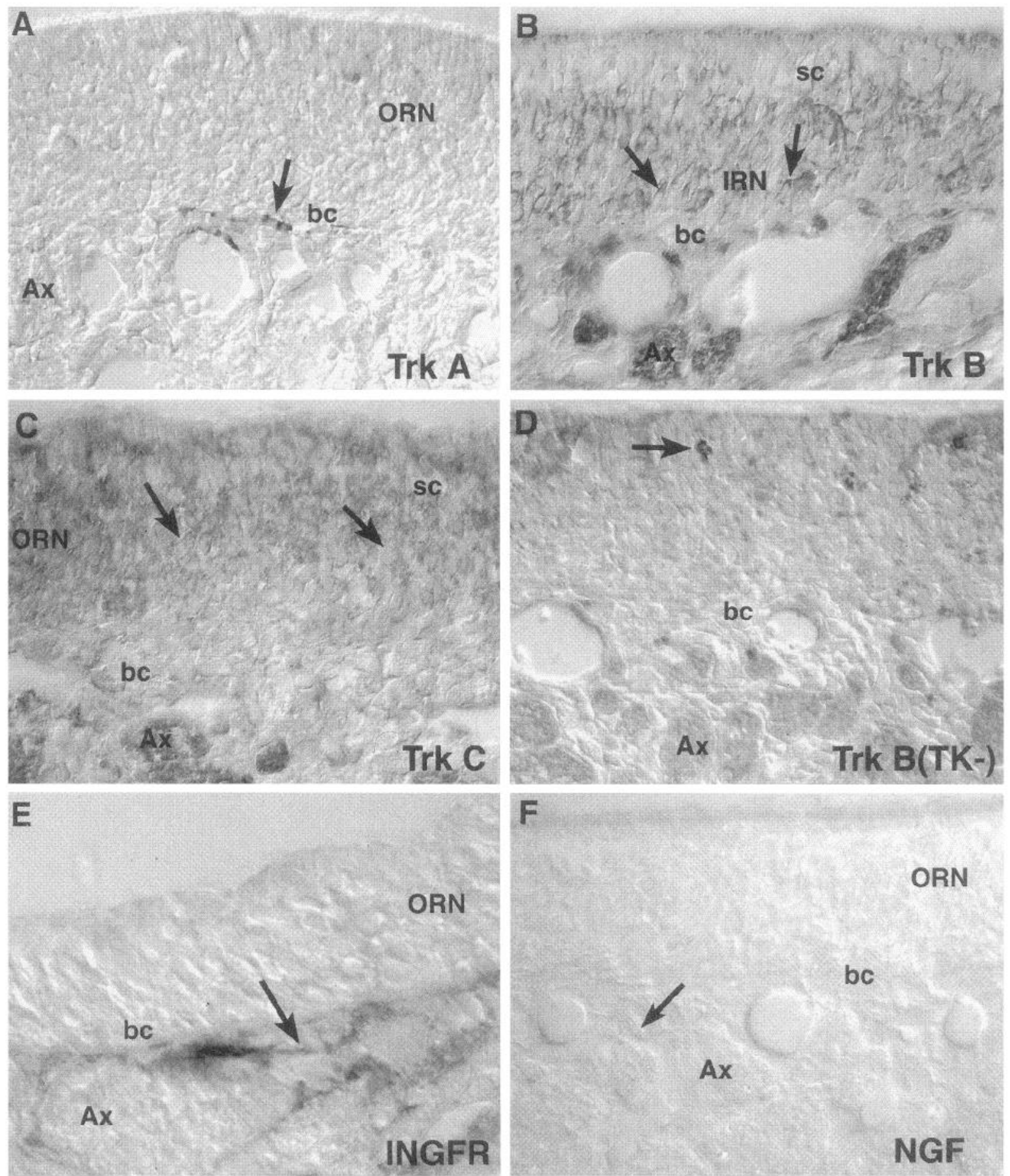

Figure 2. Distribution of Trks and INGFR in adult olfactory tissue. Frozen cross-sections of adult olfactory tissue (10 $\mu \mathrm{m})$ were examined immunohistochemically for the distribution of $\operatorname{Trk} A(A), \operatorname{Trk} B(B)$, Trk $C(C)$, truncated Trk B (Trk B Tk-) $(D), l N G F R(E)$, and NGF $(F)$. Trk A IR is observed in basal cells $(b c$, arrow), and Trk B IR is observed in immature neurons (IRN, arrow) and axons (Ax) of mature neurons (ORN). Trk C IR is seen throughout the neuronal layer, but not in basal cells or sustentacular cells $(s c)$. INGFR IR is observed in glia of the olfactory nerve layer (arrow) of the lamina propria.

layer becomes positive for Trk A (Fig. 4C,D). Between 1 and 2 weeks after bulbectomy, Trk A IR also is seen in a "capping" pattern above the nucleus of newly generated ORNs, indicative of proteins that are packaged in the endoplasmic reticulum but not transported to a programmed cellular location. By 3 weeks after bulbectomy, Trk A IR in basal cells has decreased in regions that have undergone neuronal replacement, but occasional pairs of presumably immature daughter neurons are strongly Trk A-positive (Fig. 4E).

NGF expression is not detected within the normal olfactory neuroepithelium, but at $3 \mathrm{~d}$ after bulbectomy, at high-power resolution, NGF IR can be detected within the olfactory neuro- 

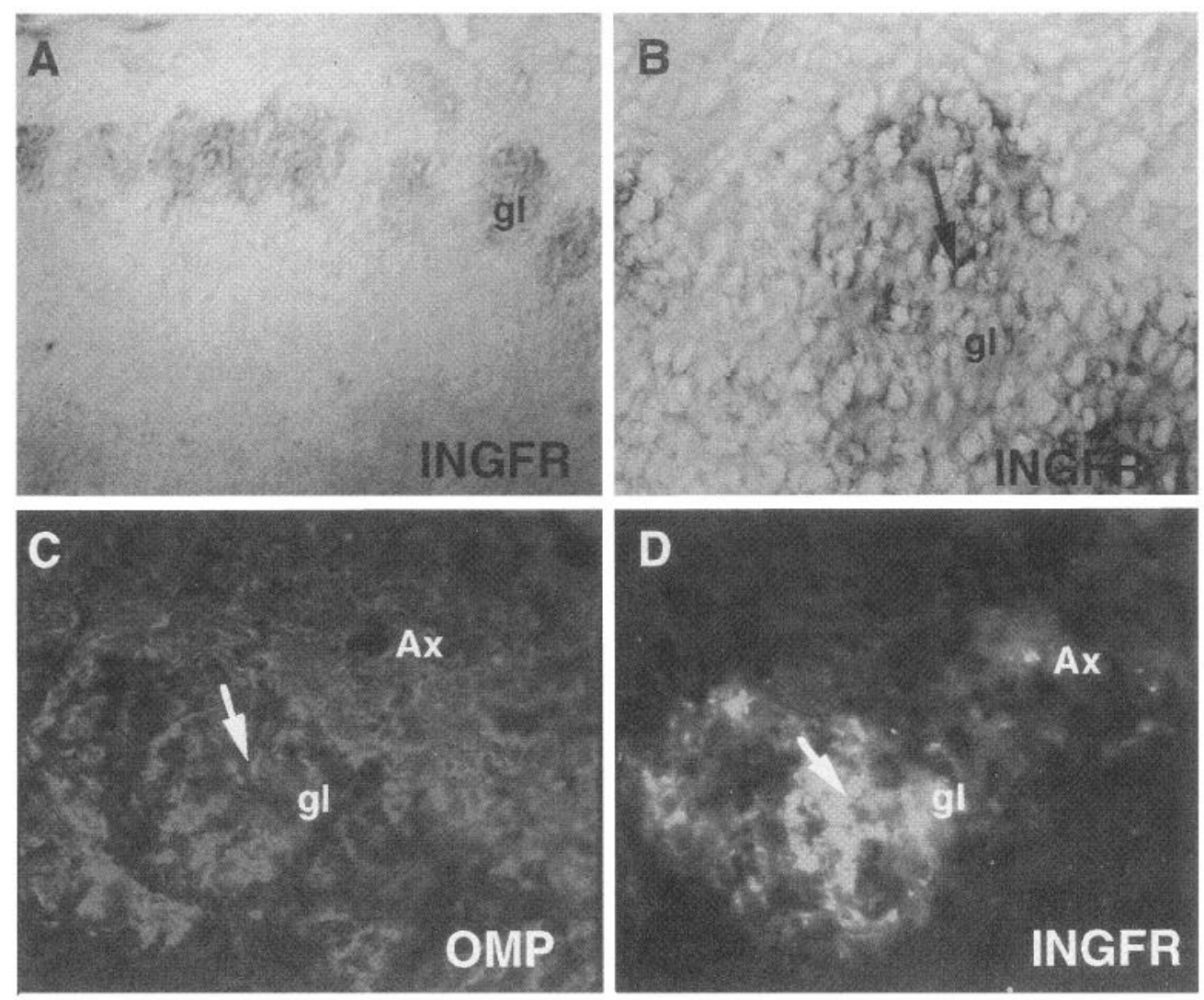

Figure 3. Localization of the INGFR to terminals of olfactory neurons in the olfactory bulb. The $I N G F R$ is seen in a glomerular $(g l)$ "necklace-like" pattern around the periphery of the olfactory bulb $(A)$ and is seen to stain in a synaptic terminal-like pattern at higher magnification $(B)$. The $O M P$ specifically stains ORN axons $(A x)$ and terminals $(C)$, and the nerve terminal staining is coincident with that of the INGFR in the same section $(D)$. epithelium in a "diffuse" pattern immediately above and around the basal cell layer (Fig. 4G). In addition, 1 week after bulbectomy, individual cells within the ORN layer with the appearance of degenerating neurons appear to express NGF strongly throughout their cytoplasm (Fig. $4 H$ ). By 2 and 3 weeks after bulbectomy, neurons actively undergoing regeneration appear to express NGF throughout their cell bodies and dendritic projections (Fig. 4I,J). Interestingly, in these same regions of replacement and repair, glial fibers coming up from the lamina propria directly beneath the horizontal basal cell layer become NGF-positive (Fig. 4I,J). This fibrous pattern of staining is not seen in adjacent areas of epithelium that are still actively undergoing cell division and neuroepithelium repair (as seen in Fig. $4 H$ ).

The basal precursor neurons do not express the INGFR, even when stimulated to divide at $3 \mathrm{~d}$ to 1 week after bulbectomy (Fig. $4 L$ ). Glial staining for the INGFR in the lamina propria is evident in the neuroepithelium immediately after bulbectomy (Fig. $4 L$ ). As olfactory neurons undergo maximum degeneration, 1 week after bulbectomy, punctate expression of INGFR is detected in individual degenerating neurons in the upper layers of the neuroepithelium (Fig. $4 M$ ), coincident with the pattern seen for NGF at this time. After completion of the first wave of neuronal cell death, by 2 and 3 weeks after bulbectomy, we do not detect INGFR expression in olfactory neurons, but occasional streaky staining for INGFR in the lamina propria returns at 3 weeks after bulbectomy (Fig. 3O).

\section{Trks A, B, and C are expressed sequentially in regenerating olfactory neurons}

Immediately after bulbectomy, Trk B-immunoreactive axon bundles and cell bodies disappear in the mature layers of the epithe- lium, as axons undergo retrograde degeneration back to the neuroepithelium and mature ORNs die (Fig. 5B). By 1 week after bulbectomy, "newborn" ORNs, situated low in the epithelium immediately above the Trk B-negative basal cell layer, are strongly immunoreactive for Trk B throughout their cell bodies (Fig. $5 C$ ). More superior degenerating olfactory neurons are still negative for Trk B. By 2 weeks after bulbectomy, strong Trk B IR is seen in new populations of immature olfactory neurons, throughout their dendritic projections and the terminal dendritic knob from which the sensory cilia will develop (Fig. 5D). Three weeks after bulbectomy, some Trk B positivity remains in cell bodies within the olfactory neuroepithelium, but IR has shifted and is concentrated in small-caliber Trk B-positive pioneer axon bundles that are seen streaming from newly generated neurons back toward the olfactory bulb (Fig. $5 E$ ).

The major truncated form of Trk B (TK-) is expressed faintly throughout axon bundles in the lamina propria underlying the neuroepithelium (Fig. 2C). This immunoreactive pattern disappears after bulbectomy, and truncated Trk B expression does not parallel that seen for Trk B at any point during the regeneration cycle (data not shown).

Trk C IR is distributed sparsely in the membranes of mature olfactory neurons in the neuroepithelium and in their primary afferent projections. At no time is Trk C IR detected in basal cells or sustentacular cells. Trk C IR appears to decrease as early as 3 $\mathrm{d}$ after bulbectomy as the neurons undergo retrograde degeneration (Fig. $5 F$ ) and is never observed to the same degree in individual neurons undergoing regeneration at 1,2 , and 3 weeks after bulbectomy (Fig. $5 G-I$ ). Trk C IR does not overlap either in Trk A-positive basal cells or in the Trk B-positive newly regener- 
Trk A
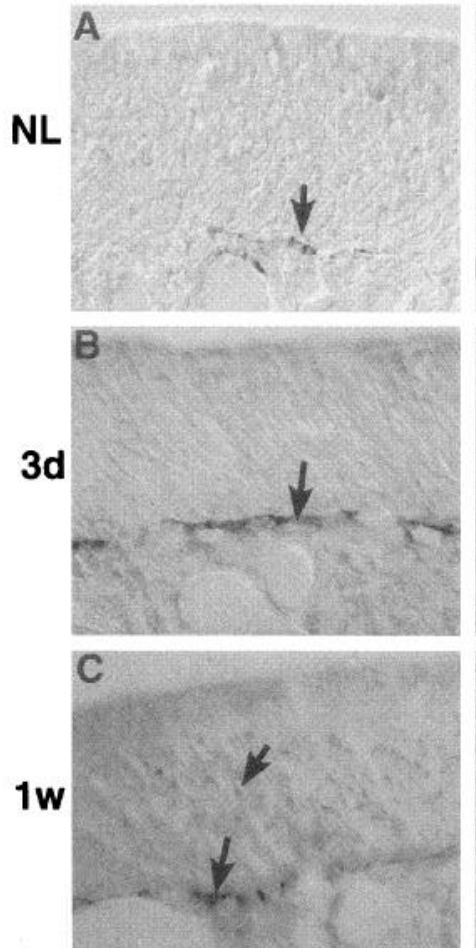

Figure 4. Trk A, NGF, and INGFR expression during olfactory neuron regeneration. Rats subjected to unilateral bulbectomy were allowed to recover for $3 \mathrm{~d}(3 d)$, 1 week (lw), 2 weeks $(2 w)$, and 3 weeks $(3 w)$. Sections of olfactory epithelium from unlesioned animals (NL) and bulbectomized animals subsequently were immunostained using a polyclonal antibody against Trk $A(A-E)$ or monoclonal antibodies against $N G F(F-J)$ and $I N G F R(K-O)$. Trk A expression $(A-E)$ is localized mainly to horizontal neuronal precursor basal cells $(B C)$ in normal and regenerating tissue $(A-D)$ but also is detected in a "capped" manner in more superior neurons (ORN) during the olfactory degeneration-regeneration cycle $(C, D)$. NGF IR is confined to the lamina propria $(L P)$ in normal olfactory tissue $(F)$, but after bulbectomy is found in regenerating neurons (arrow) as they migrate through the neuroepithelium. NGFR IR also is confined to the lamina propria $(K)$ in normal neuroepithelium but is expressed in a punctate manner in cells resembling dying neurons high in the degenerating-regenerating epithelium (arrow, $M$ ).
NGF
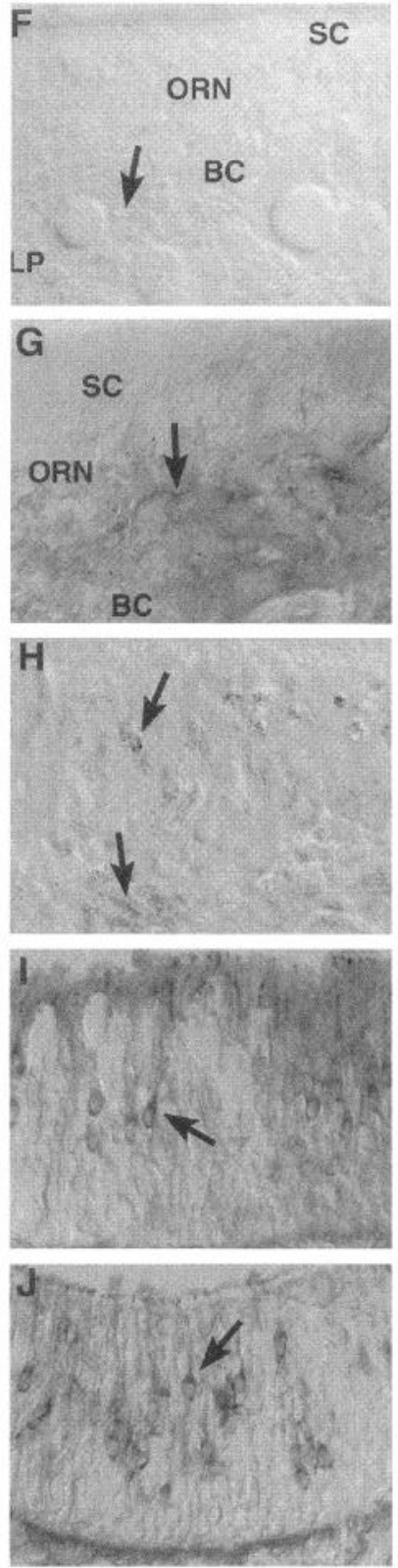

INGFR
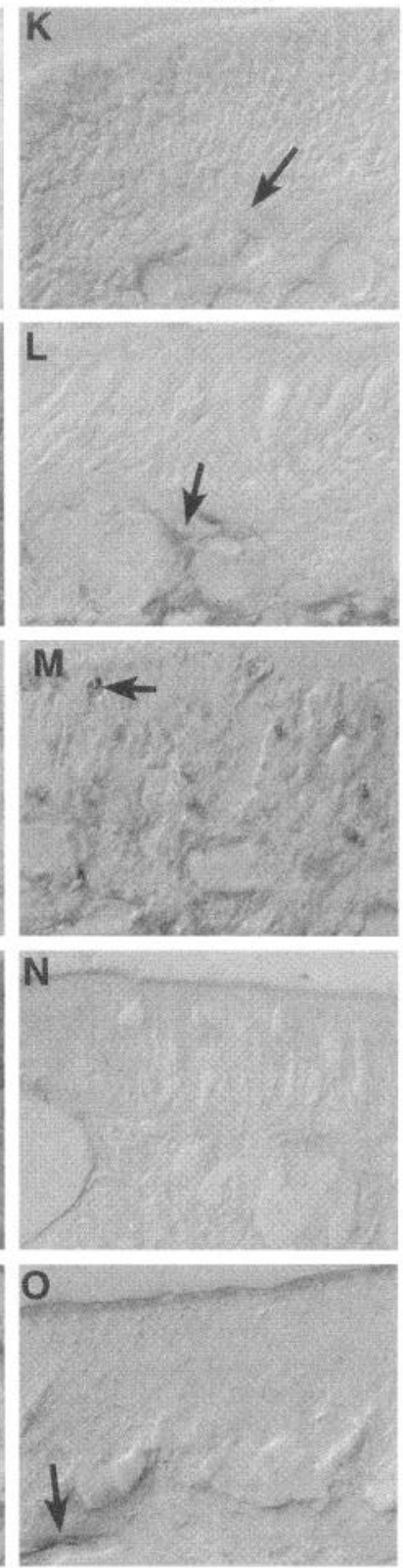

ated immature neurons, but mature neurons appear to express both Trk B and Trk C.

Although a spatio-temporal pattern of Trk expression strongly suggests a neurotrophin-driven differentiation pattern of olfactory neurons, it does not provide mechanistic evidence that the receptors expressed possess tyrosine kinase activity and drive neurotrophin-induced signal transduction machinery to induce morphological and immediate or long-term gene expression changes in olfactory neurons. To address these questions, we have examined Trk expression and activation by neurotrophins in primary cultures of olfactory neurons that contain olfactory neurons at different stages of their developmental life cycle.

Trks A, B, and C are expressed at different stages of olfactory neuron differentiation in vitro

A similar correlation between neuronal maturity and sequential expression of Trks $\mathrm{A}, \mathrm{B}$, and $\mathrm{C}$ is seen in olfactory neurons in vitro.
Several well defined markers for olfactory neuron development have been used to demonstrate the presence of olfactory neurons at different stages of maturity in vivo and in vitro. Cytokeratin clearly marks groups of epithelioid basal cells that are identified easily in vitro and are always found in small clumps of 6-12 cells (Fig. 6A). Trk A positivity is also observed in two cells within a clump of basal cells (Fig. 6B) and is not detected on any other cells in this culture system.

After precursor cell division, immature neurons are marked specifically with the cell adhesion molecule L-1 (NGF-inducible large external glycoprotein) and GAP-43, which is found throughout the cell bodies and processes of immature neurons and is restricted to the processes only of more mature neurons (Fig. $6 C, D)$. Trk B IR also is clearly detected within the cell bodies and neurites of neurons at an early developmental stage when a Trk B-positive single neuronal process is observed (Fig. $6 F$ ) as well as in neurons of a more bipolar mature phenotype (Fig. $6 H$ ). 
Trk B
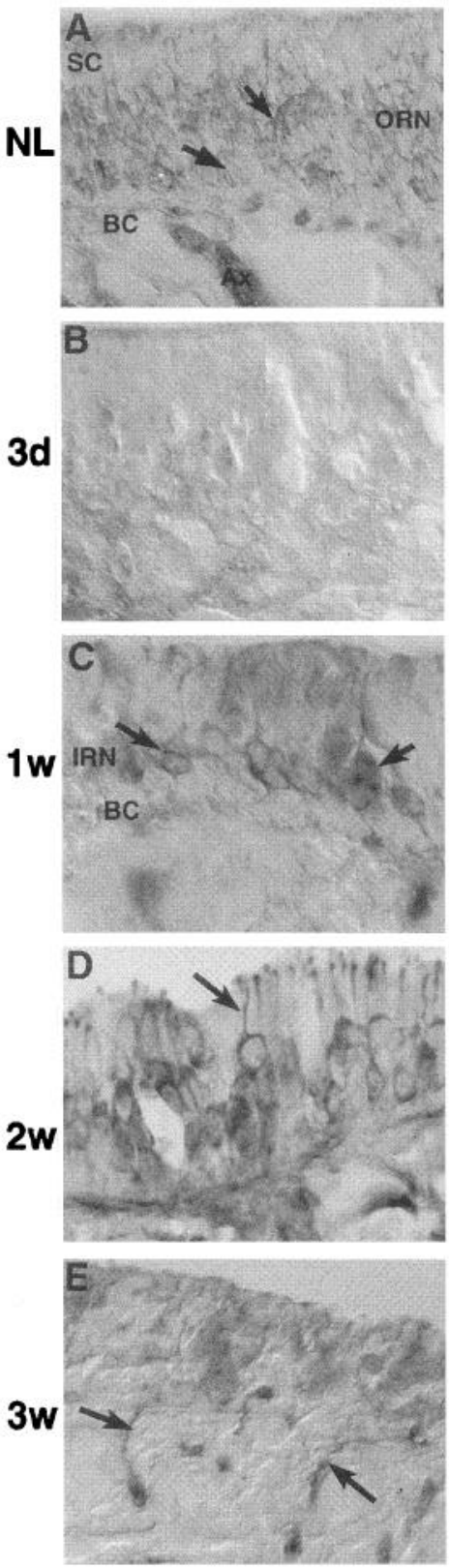

Trk C
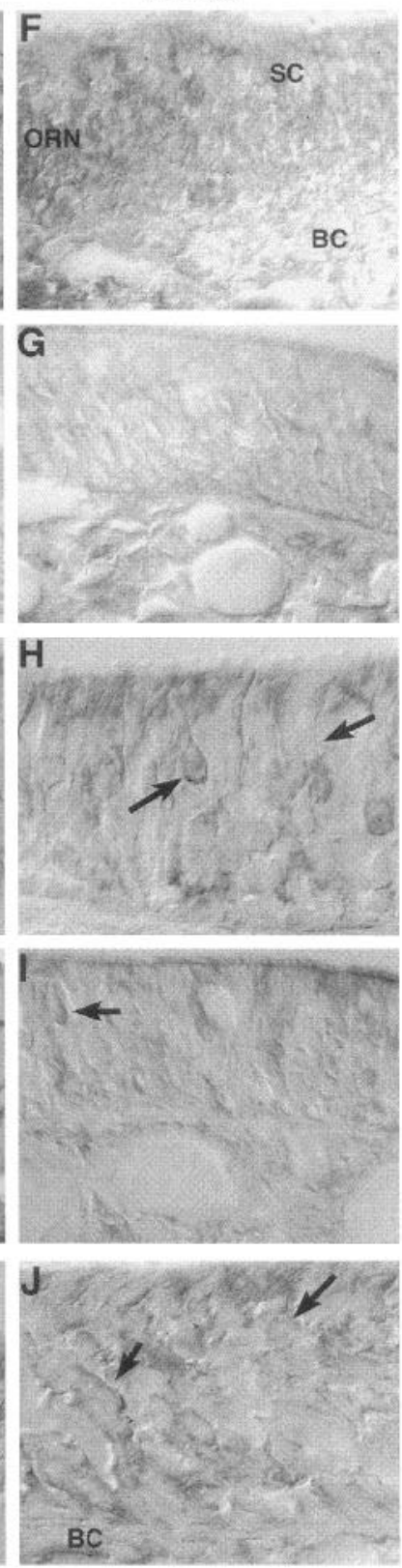

Figure 5. Trk B and Trk C expression during olfactory neuron regeneration. Rats that were unilaterally bulbectomized were allowed to recover for $3 \mathrm{~d}(3 d), 1$ week $(1 w), 2$ weeks $(2 w)$, and 3 weeks $(3 w)$. Sections of olfactory epithelium from unlesioned animals $(N L)$ and bulbectomized animals subsequently were immunostained using a polyclonal antibody against $\operatorname{Trk} B$, truncated Trk B, and $\operatorname{Trk} C$. Trk B is expressed at high levels in both immature and mature olfactory neurons $(O R N, A)$ and throughout their afferent axons in normal neuroepithelium. During degeneration, Trk B IR decreases $(B)$, but expression of Trk B reappears in the cell bodies of olfactory neurons undergoing regeneration $(C, D)$ and is seen in pioneering axons leaving the epithelium (arrows, $E$ ) as the neurons mature. Trk $\mathrm{C}$ is expressed faintly in the meshwork of neuronal membranes within olfactory neurons $(O R N, F)$ but is totally absent from sustentacular cells $(S C)$ and basal cells $(B C)$. IR disappears as mature neurons degenerate $(G, H)$ and holes of degeneration appear in the epithelium $(I)$ but reappears in occasional neurons that are undergoing regeneration $(J)$.

N-CAM IR is detected clearly from the earliest phenotypically immature neurons to neurons with a more elongated, mature phenotype. This pattern and distribution of IR are mirrored exactly by those observed for Trk B in olfactory neurons in vitro (Fig. 6E).

Mature olfactory neurons express a specific olfactory marker, the OMP, in vivo and in vitro. Elongated, mature neurons express OMP in this culture system, and neurons with this phenotype also express Trk $\mathrm{C}$ in a very punctate, perinuclear pattern and in a very sparse, yet specific manner in their processes.

Having established the presence of Trks A, B, and C in our primary culture system, we decided to examine whether this is a viable neuronal primary culture system for biochemically assessing the ability of the Trk receptor family to bind and transduce neurotrophin-induced signals.

\section{Trks A, B, and C autophosphorylate in response to neurotrophin challenge}

Primary cultures of olfactory neurons, which contain neurons at both mature and immature stages of development, were stimulated with NGF, BDNF, NT-4, and NT-3 after a serum deprivation period of $24 \mathrm{hr}$. After neurotrophin treatment, cells were lysed and proteins subsequently were either immunoprecipitated with anti-Trk antibodies and probed with a monoclonal antiphosphotyrosine antibody (Fig. 7A) or, alternatively, immunoprecipitated with a polyclonal anti-phosphotyrosine antibody and probed with specific anti-Trk antibodies (Fig. $7 B$ ).

Trk A becomes specifically phosphorylated in primary ORN cultures when challenged with NGF. Trk B is phosphorylated when challenged with both BDNF and NT-4, with a higher degree of phosphorylation of BDNF, which suggests a stronger effect of this neurotrophin. Trk $\mathrm{C}$ becomes phosphorylated when treated with NT-3, demonstrating that each Trk receptor behaves in an appropriate manner for stimulating downstream cytoplasmic pathways. A low, basal phosphorylation is detected in the control lanes of each immunoprecipitation experiment (the - column) without the addition of exogenous neurotrophin, suggesting that some form of highaffinity neurotrophin is being synthesized by some cell types in the primary cultures. Studies to determine which neuroepithelial cell type is responsible for neurotrophin production both in vivo and in vitro are currently in progress. The level of phosphorylation of each Trk is decreased specifically when the ORN cultures are treated with neurotrophin in the presence of the Trk inhibitor K252a (Fig. 7A) (Berg et al., 1992).

\section{c-Fos induction via stimulation of Trk receptors}

Primary cultures of olfactory neurons were stimulated with NGF, BDNF, NT-4, and NT-3 and assessed for induction of the cellular oncogene c-Fos by Northern blot analysis (Fig. 8). c-Fos induction is observed at $40 \mathrm{~min}$ after growth factor-induced stimulation with NGF, BDNF, and NT-3. When the receptor kinase inhibitor $\mathrm{K} 252 \mathrm{a}$ is added concurrently with the neurotrophin, c-Fos induction is blocked, indicating that the neurotrophins are acting through Trk receptors to effect growth factor-induced transcription of c-Fos within olfactory neurons.

\section{Neurotrophins act in concert to increase numbers of differentiating olfactory neurons in vitro}

To assess whether the biochemical activation of Trk-mediated pathways causes a phenotypic change in olfactory neurons in vitro, primary cultures of olfactory neurons were treated with neurotrophins, either individually or in combination, and the effectiveness of the growth factors was assessed by immunohistochemically 
Figure 6. Trks A, B, and C are expressed in phenotypically different populations of olfactory neurons in vitro. Primary cultures of olfactory neurons were examined immunohistochemically for their expression of cytokeratin $(A)$, which is observed in clumps of basal cells, and Trk $A(B)$, which is detected in occasional cells within clumps of basal cells (arrow). Trk $B$ expression $(F)$ is detected first in the cell bodies and neurite of unipolar immature neurons that also display IR for $L 1(C), G A P-43(D)$, and $N$-CAM $(E)$. Trk B expression also is detected in more mature, bipolar, spindleshaped neurons $(H)$ that display IR for Trk $C(I)$ and $O M P(G)$.

\section{STAGE 1 neuronal precursors}
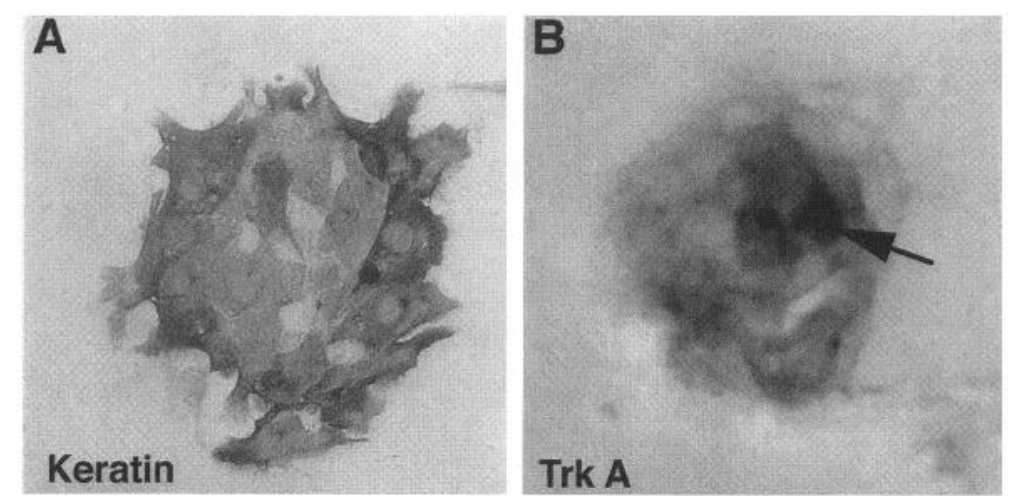

\section{STAGE 2 immature neurons}
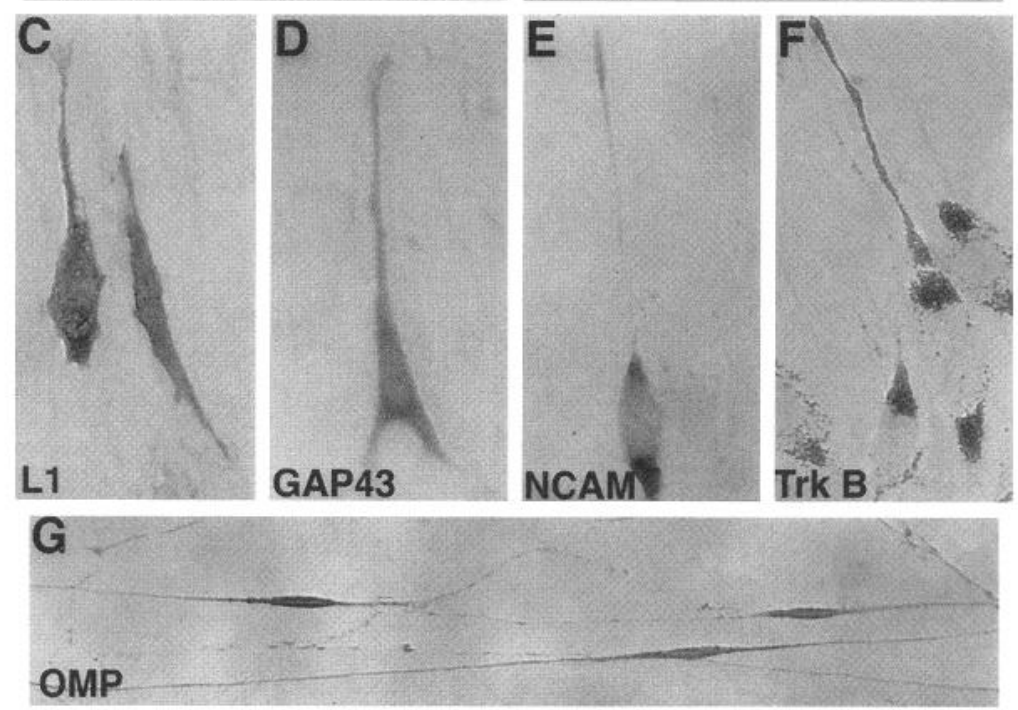

\section{STAGE 3 mature neurons}
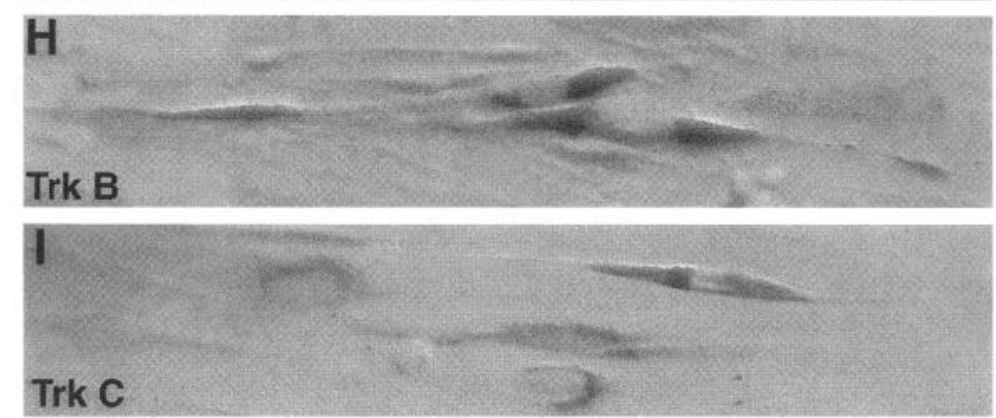

analyzing the numbers of N-CAM-positive neurons and GAP-43positive neurons/neurites after $3 \mathrm{~d}$ of growth factor treatment (Fig. 9). Both NT-3 $(p<0.05)$ and BDNF $(p<0.01)$ added individually significantly increased the number of N-CAM/GAP43-positive neurons. The most effective increase in differentiating neurons $(p<0.01)$ was achieved when NGF and BDNF were added in combination, whereas when NT-3 was added to this combination, the number of N-CAM/GAP-43-positive neurons increased significantly but was less effective than NGF/BDNF alone.

\section{DISCUSSION}

These results provide evidence to demonstrate that ORNs sequentially express the entire family of neurotrophin receptors at different stages of maturity, both in vivo and in vitro, and can respond to each member of the neurotrophin family to promote the terminal differentiation of olfactory neurons.

\section{What is the function of the INGFR in this system?}

The INGFR is expressed at both the mRNA and protein levels in primary cultures of olfactory neurons and normal olfactory tissue, and yet the INGFR IR is not detected within ORN cell bodies or axons at any point during growth and differentiation, although this has been reported by others (Aiba et al., 1993; Miwa et al., 1993; Ramon-Cueto et al., 1993). This argues that, during olfactory neurogenesis, Trks A, B, and C work independently of the INGFR. INGFR is not located suitably either to sequester the neurotrophins at the cell surface for presentation to Trk receptors or to mediate any direct interaction between the INGFR and Trk receptors within the olfactory neuroepithelium (Jing et al., 1992). The IR observed for both NGF and the INGFR beneath the neuroepithelium does not preclude the possibility that glial cells in the lamina propria are binding NGF and controlling the supply of NGF to Trk A-positive (NGF-sensitive) basal cells lying immedi- 


\section{A. Anti-Phosphotyrosine Immunoblot/Trk Immunoprecipitation}

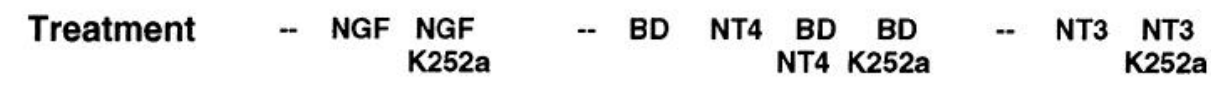

200-

120-

80-

IPP Antibody

Trk A $\quad$ Trk B

Trk B $\quad$ I Trk C

\section{B. Anti-Trk Immunoblot/ PhosphoTyrosine Immunoprecipitation

$\begin{array}{llllllll}\text { Treatment } & - & \text { NGF } & - & \text { BD NT4 } & \text { BD } & - & \text { NT3 }\end{array}$

200-

$120-$

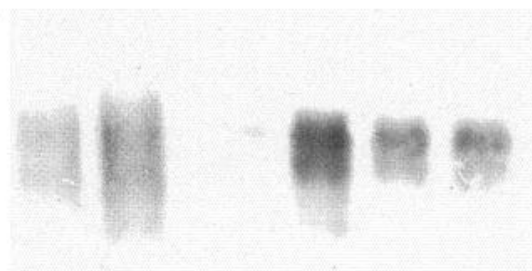

80-

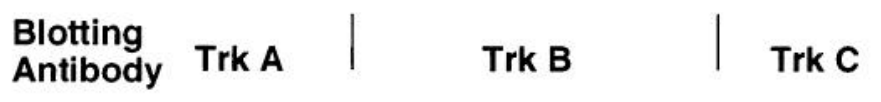

Figure 7. Trks A, B, and C become phosphorylated when challenged with neurotrophins. A, Primary cultures of olfactory neurons were starved for $24 \mathrm{hr}$ before being treated with $N G F$, BDNF $(B D)$, and $N T-3$ for $10 \mathrm{~min}$ before lysis and subsequent immunoprecipitation with anti-Trk A, -Trk B, and -Trk C antibodies. Immunoprecipitates were separated by PAGE and blotted to nitrocellulose membranes before being immunoblotted with monoclonal anti-phosphotyrosine antibody. Control cultures were treated with media alone (-), and parallel wells were treated with neurotrophin in the presence of the tyrosine kinase inhibitor $K 252 a(100 \mathrm{nM})$. $B$, Primary cultures of olfactory neurons were starved for $24 \mathrm{hr}$ before being treated with $N G F$, BDNF $(B D)$, and $N T-3$ for 10 min before lysis and subsequent immunoprecipitation with a polyclonal antiphosphotyrosine antibody. Immunoprecipitates from culture wells treated in parallel with media alone (-), neurotrophin, and neurotrophin plus K252a were subsequently immunoblotted for Trks A, $\mathrm{B}$, and $\mathrm{C}$, and results were compared with those obtained in $A$. ately superior to the lamina propria (Johnson et al., 1988; Hantzopoulos et al., 1994). It is important to note, in support of this, that when the Trk A-positive basal cells need NGF most, at peak times of mitosis, glial IR for the INGFR decreases (1 week after bulbectomy). As repair within the neuroepithelium progresses and the rate of mitosis decreases, glial IR for the INGFR in the olfactory nerve layer is restored ( 3 weeks after bulbectomy).

The INGFR is detected, however, in the cell bodies of neurons that appear to be degenerating, which are also concurrently positive for NGF protein. The coexpression of NGF and the INGFR could indicate that the degenerating neurons are producing NGF locally to signal the Trk A-positive basal cells in the same region to begin the program of neuronal replacement. The presence of NGF within regenerating populations of olfactory neurons after bulbectomy also is intriguing, and these neurons could be producing NGF locally (as they do embryonically, before the formation of the olfactory bulb) to compensate for NGF not being produced by their mature mitral cell target neurons in the olfactory bulb (Williams and Rush, 1988; Guthrie and Gall, 1991).

\section{Does Trk A enhance olfactory neurogenesis and commitment?}

Trk A IR is detected in sparse groups of neuronal precursor basal cells in the normal olfactory neuroepithelium. During coordinated regeneration of olfactory neurons, however, Trk A IR is detected throughout the entire basal cell population, suggesting that Trk A and its ligand NGF are involved in the early neurogenic and commitment response of basal cells, independent of the INGFR. In regions that have partially completed the neurogenesis cycle and in which physical repair of the neuroepithelium is apparent, Trk A IR decreases, suggesting a density-dependent local control of neurogenesis in vivo. Trk A IR no longer is detectable once olfactory neurons leave the cell cycle and proceed into the early stages of neuronal differentiation. The sparsity of Trk A IR in the normal neuroepithelium argues against a role for NGF in enhancing survival of neuronal precursors.

In primary cultures of olfactory neurons, Trk A IR is detected on a small percentage of cytokeratin-positive basal cells. When 


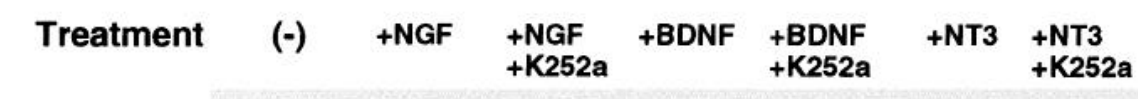

$5 \mathrm{~Kb}$ -

Cfos -

$2.8 \mathrm{~Kb}$ -

Figure 8. c-Fos expression is induced by NGF, BDNF, and NT-3 in primary cultures of olfactory neurons. Primary cultures of olfactory neurons were treated with media alone $(-)$, media supplemented with neurotrophin $(+N G F,+B D N F,+N T-3)$, or neurotrophin plus $K 252 a$. After a $40 \mathrm{~min}$ treatment, cells were lysed, RNA was prepared from each treatment group, and Northern blot analysis using a probe against c-Fos reveals that c-fos is induced via a neurotrophin-Trk interaction and is blocked when the tyrosine kinase inhibitor $\mathrm{K} 252 \mathrm{a}$ is present at physiological concentrations.

18s rRNA -

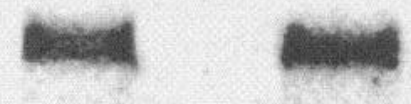

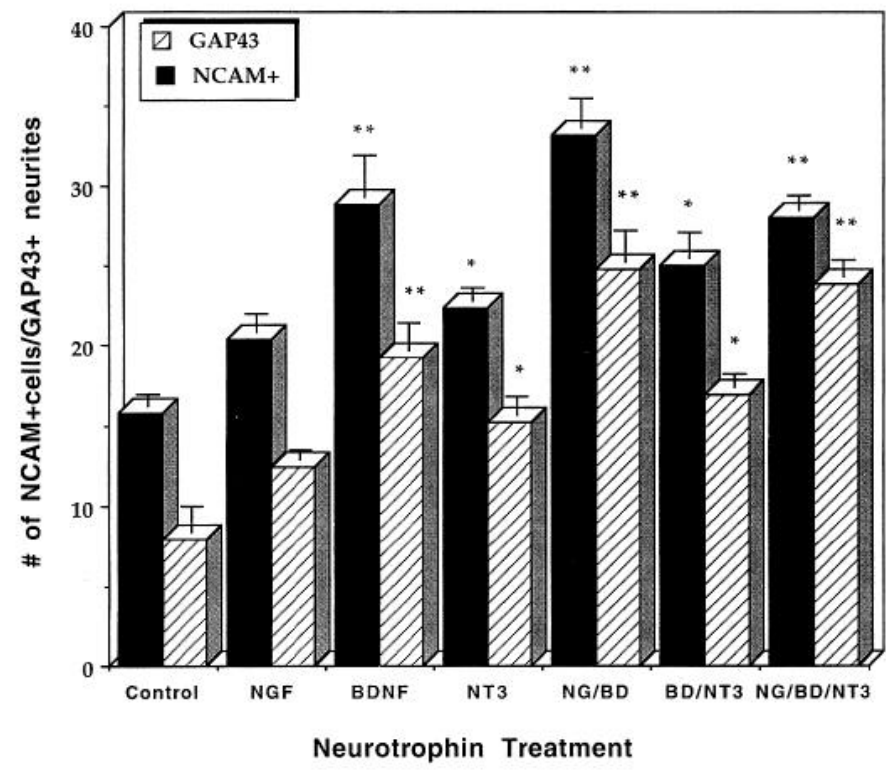

Figure 9. Olfactory neurons mature in vitro under the influence of neurotrophins. Primary cultures of olfactory neurons were treated with $N G F$, $B D N F$, and $N T 3$ individually and in combination and subsequently stained for N-CAM $(N C A M+)$ and $G A P-43(G A P 43)$, which should indicate the population of "differentiating" neurons, that is, those undergoing transition from immature to mature phenotype. Numbers of N-CAM- and GAP-43-positive neurons were counted, and the treatment was analyzed by a Student's $t$ test to have produced significant $(p<0.05)$ or highly significant $(p<0.01)$ increases in the number of differentiating neurons compared with control cultures that were grown without the addition of neurotrophins (Control).

these cultures are treated with NGF, phosphorylation of Trk A is observed and c-Fos transcription increases within $40 \mathrm{~min}$ after treatment of NGF. Both of these effects are blocked by concurrent treatment with $\mathrm{K} 252 \mathrm{a}$, a specific receptor tyrosine kinase inhibitor. NGF treatment alone, however, does not appear to enhance significantly the number of postmitotic N-CAM-positive neuronal cells present in vitro. The marked upregulation of Trk A during neurogenesis in vivo, in conjunction with a detectable activation of NGF-Trk A-driven biochemical and molecular pathways in vitro, suggests that NGF stimulates basal cells to divide and commit to a neuronal lineage during regeneration of olfactory neurons in the adult animal.

How may NGF signal this novel neurogenic mechanism? Epidermal growth factor, transforming growth factor (TGF)- $\alpha$, and TGF- $\beta$ stimulate a differentiation response in olfactory neurons, and their receptors have been demonstrated on early olfactory precursors (Mahanthappa and Schwarting, 1993; Farbman, 1994). It is conceivable, therefore, that these different peptide growth factors could act in concert with Trk A to signal downstream pathways to initiate the olfactory neuron development program, as has been demonstrated for the induction of differentiation in embryonic cultures of neurons and oligodendrocyte O2A progenitor cells (Barres et al., 1993; DeHamer et al., 1994).

\section{Trk B drives early neuronal differentiation of the ORN}

Trk B IR is observed first in olfactory neurons that have undergone division, no longer express Trk $\mathrm{A}$, and are in the immature (GAP-43-positive) state. In immature neurons, Trk B expression is distributed throughout the cell body and is particularly strong in dendritic processes and the dendritic knobs of newly generated immature neurons lying low in the neuroepithelium. Trk B IR is retained as olfactory neurons migrate to a more mature, superior placement in the epithelium, but Trk B IR shifts significantly into the outgrowing axons that are leaving the epithelium and projecting toward the olfactory bulb. This pattern of expression suggests that progression of olfactory neurons through the early postmitotic stages of differentiation is dependent on Trk B activation, in agreement with a proposed role for BDNF in other sensory neuron populations (Johnson et al., 1986a,b; Schecterson and Bothwell, 1992; Segal et al., 1992; Wright et al., 1992; Ernfors et al., 1994) and with previous studies that have suggested that 
BDNF is the most crucial neurotrophin for promoting the matu ration and survival of ORNs in vitro (Mahanthappa and Schwarting, 1993).

Trk B IR is detected strongly in axon bundles of the mature olfactory epithelium, suggesting that once Trk B has mediated neuronal maturation through juvenile stages within the epithelium, it subsequently mediates a trophic interaction between the olfactory neuron and the olfactory bulb, similar to that suggested for the retina (Johnson et al., 1986b). The upregulation of Trk B expression in the regenerating axons is consistent with its transducing an immediate protective signal after axonal injury (Merlio et al., 1993; Morse et al., 1993).

Trk B expression is detected clearly in phenotypically immature and mature olfactory neurons in vitro, and these neurons respond to challenges with both NT-4 and BDNF by rapidly phosphorylating the full-length version of Trk $\mathrm{B}$ and then inducing transcription of c-Fos. BDNF alone is the most highly effective neurotrophin in promoting the differentiation of olfactory neurons in this study and is even more effective when added in combination with NGF. Thus, differentiation and survival of olfactory neurons appear to be highly dependent on activation of Trk B by either BDNF or NT-4. BDNF clearly elicits a stronger phosphorylation of Trk B and induction of c-fos than NT-4, and an additive effect is not observed when both are added concurrently. However, we cannot preclude the possibility that NT-4 may play a significant role when BDNF is in short supply (Jones et al., 1994).

\section{Trk C maintains healthy, mature ORNs}

Trk C IR is distributed diffusely throughout the membranes of mature olfactory ncurons and their axons, in a pattern similar to that observed for the OMP, but less intense. This suggests that a more likely role for Trk C and NT-3 is to maintain olfactory neurons in their mature state within the olfactory neuroepithelium after they have differentiated fully, similar to the phenomenon suggested for cerebellar granule cell neurons and developing muscle sensory neurons (Segal et al., 1992; Hory-Lee et al., 1993). This hypothesis is supported by the fact that NT-3 transcripts also have been found in RNA from the neuroepithelium and primary cultures of ORNs by Northern and PCR analysis data (A. Roskams and G. Ronnett, unpublished observations). As mature neurons degenerate and die, Trk C IR decreases. During degeneration of the epithelium, Trk C IR becomes apparent in the cytoplasm of some individual neurons, suggesting an upregulation of growth factor-mediated pathways at the cellular level in an effort to extend their lifespan and scavenge for NT-3 to increase survival (Schnell et al., 1994). Trk C is present in mature ORNs in vitro, is phosphorylated in the presence of NT-3, and induces transcription of c-Fos. Thus, both Trk B and Trk C are stimulated strongly by their high-affinity ligand in ORNs, a phenomenon previously demonstrated only in phenotypically mixed neuronal cultures (Segal et al., 1992; Ip et al., 1993b).

Within the olfactory neuroepithelium, the expression of neurotrophin receptors depends chiefly on the stage of differentiation of each individual olfactory neuron. Trk receptors therefore appear to mediate different growth-related events during olfactory neuron division, commitment, differentiation, and maturation. This study provides data to suggest how neurogenesis within the olfactory neuroepithelium is controlled by both local and targetderived supply of neurotrophins, and it demonstrates increased differentiation and survival of olfactory neurons by combinations of neurotrophins. These observations give a novel insight into how neurotrophins influence the birth, life cycle, and possible death program of sensory neurons and subsequently support the use of olfactory neurons as a system in which the signal transduction systems stimulated by neurotrophins in both developing and adult neurons can be tested and determined.

\section{REFERENCES}

Aiba T, Mori J, Nakai Y (1993) Nerve growth factor (NGF) and its receptor in rat olfactory epithelium. Acta Otolaryngol Suppl 506:37-40.

Barbacid M (1993a) Nerve growth factor: a tale of two receptors. Oncogene 8:2033-2042.

Barbacid M (1993b) The Trk family of neurotrophin receptors: molecular characterization and oncogenic activation in human tumors. In: Molecular genetics of nervous system tumors (Levine AJ, Schmidik HH, eds), pp 123-136. New York: Wiley-Liss.

Barber PC, Lindsay RM (1982) Schwann cells of the olfactory nerves contain glial fibrillary acidic protein and resemble astrocytes. Neuroscience 7:3077-3090.

Barde YA (1989) Trophic factors and neuronal survival. Neuron 2:1525-1534.

Barres BA, Schmid R, Sendter M, Ratt MC (1993) Multiple extracellular signals are required for long-term oligodendrocyte survival. Development 118:283-295.

Berg MM, Sternberg DW, Parada LF, Chao MV (1992) K-252a inhibits nerve growth factor-induced trk proto-oncogene tyrosine phosphorylation and kinase activity. J Biol Chem 267:13-16.

Berkemeirer LR, Winslow JW, Kaplan DR, Nikolics K, Goeddel DV, Rosenthal A (1991) Neurotrophin-5: a novel neurotrophic factor that activates trk and trkB. Neuron 7:857-866.

Calof AL, Chikaraishi DM (1989) Analysis of neurogenesis in a mammalian neuroepithelium: proliferation and differentiation of an olfactory neuron precursor in vitro. Neuron 3:115-127.

Carr VM, Farbman AI (1992) Ablation of the olfactory bulb up-regulates the rate of neurogenesis and induces precocious cell death in olfactory epithelium. Exp Neurol 115:55-59.

Cordon-Cardo C, Tapley P, Jing S, Nanduri V, O'Rourke E, Lamballe F, Kovary D, Klein R, Jones KR, Reichardt LF, Barbacid M (1991) The trk tyrosine protein kinase mediates the mitogenic properties of nerve growth factor and neurotrophin-3. Cell 66:173-183.

DeHamer MK, Guevera JL, Hanno K, Olwin BB, Calof AL (1994) Genesis of olfactory neurons in vitro: regulation of progenitor cell divisions by fibroblast growth factors. Neuron 13:1083-1097.

DiCicco-Bloom E, Friedman E, Friedman WJ, Black IB (1993) NT-3 stimulates sympathetic neuroblast proliferation by promoting precursor survival. Neuron 11:1101-1111.

Eide F, Lowenstein D, Reichardt L (1993) Neurotrophins and their receptors: current concepts and implications for neurologic disease. Exp Neurol 121:200-211.

Ernfors P, Ibanez CF, Ebendal T, Olson L, Persson H (1990) Molecular cloning and neurotrophic activities of a protein with structural similarities to nerve growth factor: developmental and topographical expression in the brain. Proc Natl Acad Sci USA 87:5454-5858.

Ernfors P, Lee KF, Jaenisch R (1994) Mice lacking brain-derived neurotrophic factor develop with sensory deficits. Nature 368:147-150.

Farbman AI (1990) Olfactory neurogenesis: genetic or environmental controls? Trends Neurosci 13:362-365.

Farbman AI (1994) Developmental biology of olfactory sensory neurons. Seminars in Cell Biol 5:3-10.

Farbman AI, Margolis FL (1980) Olfactory marker protein during ontogeny: immunohistochemical localization. Dev Biol 74:205-215.

Farbman AI, Squinto LM (1985) Early development of olfactory receptor cell axons. Brain Res 351:205-213.

Glass DJ, Yancopoulos GD (1993) The neurotrophins and their receptors. Trends Cell Biol 3:262-268.

Glass DJ, Nye SH, Hantzopoulos P, Macchi MJ, Squinto SP, Goldfarb M, Yancopoulos GD (1991) TrkB mediates BDNF/NT-3-dependent survival and proliferation in fibroblasts lacking the low affinity NGF receptor. Cell 66:405-413.

Gong Q, Baily MS, Pixley SK, Ennis M, Shipley MT (1994) Localization and regulation of low affinity nerve growth receptor expression in the rat olfactory system during development and regeneration. J Comp Neurol $344: 336-348$. 
Graziadei PPC (1971) The olfactory mucosa of vertebrates. Hand Sens Physiol 1:27-58.

Graziadei PPC, Graziadei M (1978) The olfactory system: a model for the study of neurogenesis and axon regeneration in mammals. In: Neuronal plasticity, (Cotman CW, ed), pp 131-153. New York: Raven. Graziadei PPC, Monti Graziadei GA (1979a) Neurogenesis and neuron regeneration in the olfactory system of mammals. I. Morphological aspects of differentiation and structural organization of the olfactory sensory neurons. J Neurocytol 8:1-18.

Graziadei PPC, Monti-Graziadei GA (1979b) Neurogenesis and neuron regeneration in the olfactory system of mammals. J Neurocytol 8:1-18.

Guthrie KM, Gall CM (1991) Differential expression of mRNAs for the NGF family of neurotrophic factors in the adult rat central olfactory system. J Comp Neurol 313:95-102.

Hallbook F, Ibanez CF, Persson H (1991) Evolutionary studies of the nerve-growth factor family reveal a novel member abundantly expressed in Xenopus ovary. Ncuron 6:845-858.

Hantzopoulos PA, Suri C, Glass DJ, Goldfarb M, Yancopoulos GD (1994) The low affinity nerve growth factor receptor. Neuron 13:187-201.

Hohn A, Leibrock J, Bailey K, Barde YA (1990) Identification and characterization of a novel member of the nerve growth factor/brainderived neurotrophic family. Nature 344:339-341.

Hory-Lee F, Russell M, Lindsay RM, Frank E (1993) Neurotrophin 3 supports the survival of developing muscle sensory neurons in culture. Proc Natl Acad Sci USA 90:2613-2617.

Ip NY, Ibanez CF, Nye SH, McClain J, Jones PF, Gies DR, Belluscio L, Le Beau MM, Espinisa III R, Squinto SP, Persson H, Yancopoulos GD (1992) Mammalian neurotrophin-4: structure, chromosomal localization, tissue distribution, and receptor specificity. Proc Natl Acad Sci USA 89:3060-3064.

Ip NY, Stitt TN, Tapley P, Klein R, Glass DJ, Fandl J, Greene LA, Barbacid M, Yancopoulos GD (1993a) Similarities and differences in the way neurotrophins interact with the Trk receptors in neuronal and non-neuronal cells. Neuron 10:137-149.

Ip NY, Yancopoulos GD, Lindsay RM (1993b) Cultured hippocampal neurons show responses to BDNF, NT3, and NT4, but not NGF. J Neurosci 13:3394-3405.

Jing S, Tapley P, Barbacid M (1992) Nerve growth factor mediates signal transduction through Trk homodimer receptors. Neuron 9:1067-1079.

Johnson Jr EM, Rich KM, Yip HK (1986a) The role of NGF in sensory neurons in vivo. Trends Neurosci 378:33-37.

Johnson Jr EM, Barde Y-A, Schwab M, Thoenen H (1986b) Brainderived neurotrophic factor supports the survival of cultured rat retinal ganglion cells. J Neurosci 6:3031-3038.

Johnson Jr EM, Taniuchi M, DiStefano PS (1988) Expression and possible function of nerve growth factor receptors on Schwann cells. Trends Neurosci 11:299-302.

Jones KR, Reichardt LF (1990) Molecular cloning of a human gene that is a member of the nerve growth factor family. Science $87: 8060-8064$

Jones KR, Farinsa I, Backus C, Reichardt LF (1994) Targeted disruption of the BDNF gene perturbs brain and sensory neuron development but not motor neuron development. Cell 76:989-999.

Kaplan DR, Hempstead BL, Martin-Zanca D, Chao MV, Parada LF (1991) The trk proto-oncogene product: a signal transducing receptor for nerve growth factor. Science 252:554-558.

Key B, Akeson RA (1990) Olfactory neurons express a unique glycosylated form of the neural cell adhesion molecule (N-CAM). J Cell Biol 110:1729-1743.

Klein R, Parada LF, Coulier R, Barbacid M (1989) $t r k$ B, a novel tyrosine protein kinase receptor expressed during mouse neural development. EMBO J 8:3701-3709.

Klein R, Jing S, Nanduri V, O'Rourke E, Barbacid M (1991a) The trk proto-oncogene encodes a receptor for nerve growth factor. Cell 65:189-197.

Klein R, Nanduri V, Jing S, Lamballe F, Tapley P, Bryant S, CordonCardo C, Jones KR, Reichardt I.F, Barbacid M (1991b) The trkB tyrosine protein kinase is a receptor for brain-derived neurotrophic factor and neurotrophin-3. Cell 66:395-403.

Lamballe F, Klein R, Barbacid M (1991) Trk C, a new member of the trk family of tyrosine protein kinases, is a receptor for neurotrophin-3. Cell 66:967-979.
Leibrock J, Lottspeich F, Hohn A, Hofer M, Hengerer B, Masiakowski P, Thoenen H, Barde Y-A (1989) Molecular cloning and expression of brain-derived neurotrophic factor. Nature 341:149-341.

Lindsay R, Wiegard S, Altar C, DiStefano PS (1994) Neurotrophic factors: from molecule to man. Trends Neurosci 17:182-189.

Mahanthappa NK, Schwarting GA (1993) Peptide growth factor control of olfactory neurogenesis and neuron survival in vitro: roles of EGF and TGF-Bs. Neuron 10:293-305.

Maisonpierre PC, Belluscio L, Squinto S, Ip NY, Furth ME, Lindsay RM, Yancopoulos GD (1990) Neurotrophin-3: a neurotrophic factor related to NGF and BDNF. Science 247:1446-1451.

Margolis FL (1985) Olfactory marker protein: from PAGE band to cDNA clone. Trends Neurol Sci 542-546.

Meakin SO, Shooter FM (1992) The nerve growth factor family of receptors. Trends Neurosci 15:323-331.

Merlio JP, Ernfors P, Kokaia Z, Middlemas DS, Bengson J, Kokaia M, Snith ML, Siesjo BK, Hunter T, Lindvall O, Persson H (1993) Increased production of the TrkB protein tyrosine kinase receptor after brain insults. Neuron 10:151-164.

Miragall F, Kadmon G, Husmann M, Schachner M (1988) Expression of cell adhesion molecules in the olfactory system of the adult mouse: presence of the embryonic form of N-CAM. Dev Biol 129:516-531.

Miwa T, Moriizumi T, Sakashita H, Kimura Y, Donjo T, Furukawa M (1993) Transection of the olfactory nerves induces expression of nerve growth factor receptor in mouse olfactory cpithclium. Ncurosci Lett 155:96-98.

Morse JK, Wiegand SJ, Anderson K, Yau Y, Cai N, Carnahan J, Miller J, DiStefano PS, Altar CA, Lindsay RM, Alderson RF (1993) Brainderived neurotrophic actor (BDNF) prevents the degeneration of medial septal cholinergic neurons following fimbria transection. J Neurosci 13:4146-4156.

Moulton DG (1974) Dynamics of cell populations in the olfactory epithelium. Ann NY Acad Sci 237:52-61.

Pixley SK (1992) The olfactory nerve contains two populations of glia, identified both in vivo and in vitro. Glia 5:269-284.

Radeke MJ, Misko TP, Hsu C, Herzenberg LA, Shooter EM (1987) Gene transfer and molecular cloning of the rat nerve growth factor receptor: a new class of receptors. Nature 325:593-597.

Ramon-Cueto A, Perez J, Nieto-Sampedro M (1993) In vitro enfolding of olfactory neurites by $\mathrm{p} 75$ receptor positive ensheathing cells from adult rat olfactory bulb. Eur J Neurol 5:1172-1180.

Ronnett GV, Hester LD, Snyder SH (1991) Primary culture of neonatal rat olfactory neurons. J Neurosci 11:1243-1255.

Rosenthal A, Goeddel DV, Nguyen T, Lewis M, Shih A, Laramee GR, Nikolics K, Winslow JW (1990) Primary structure and biological activity of a novel human neurotrophic factor. Neuron 4:767-773.

Roskams AJI, Friedman V, Wood CM, Walker L, Owens GA, Stewart DA, Altus MS, Danner DB, Liu X-T, McClung JK (1993) Cell cycle activity and expression of prohibitin mRNA. J Cell Physiol 157:289-295.

Roskams AJI, Bredt DS, Dawson TM, Ronnett GV (1994) Nitric oxide mediates the formation of synaptic connections in developing and regenerating olfactory receptor neruons. Ncuron 13:289-299.

Schecterson LC, Bothwell M (1992) Novel roles for neurotrophins are suggested by BDNF and NT-3 mRNA expression in developing neurons. Neuron 9:449-463.

Schneider R, Schweiger M (1991) A novel modular mosaic of cell adhesion motifs in the extracellular domains of the neurogenic trk and trkB tyrosine kinase receptors. Oncogene 6:1807-1811.

Schnell L, Schneider R, Kolbeck R, Barde YA, Schwab ME (1994) Neurotrophin-3 enhances sprouting of corticospinal tract during development and after adult spinal cord lesion. Nature 367:170-173.

Schwartz Levy M, Chikaraishi DM, Kauer JS (1991) Characterization of potential precursor populations in the mouse olfactory epithelium using immunocytochemistry and autoradiography. J Neurosci 11:3556-3564.

Schwob JE, Mieleszko Szumowski KE, Stasky AA (1992) Olfactory sensory neurons are trophically dependent on the olfactory bulb for their prolonged survival. J Neurosci 12:3896-3919.

Segal RA, Takahashi H, McKay RDG (1992) Changes in neurotrophin responsiveness during the development of cerebellar granule neurons. Neuron 9:1041-1052.

Snider WD, Johnson Jr EM (1989) Neurotrophic molecules. Ann Neurol 26:489-506. 
Soppet D, Escandon E, Maragos J, Middlemas DS, Rcid SW, Blair J, Burton LE, Stanton BR, Kaplan DR, Hunter T, Nikolies K, Parada LF (1991) The neurotrophic factors brain-derived neurotrophic factor and neurotrophin-3 are ligands for the trkB tyrosine kinase receptor. Cell 65:895-903.

Suzuki Y, Takeda M (1993) Basal cells in the mouse olfactory epithelium during development: immunohistochemical and electron-microscopic studies. Dev Brain Res 73:107-113.

Thoenen H (1991) The changing scene of neurotrophic factors. Trends Neurosci 14:165-170.

Valenzuela DM, Maisonpierre PC, Glass DJ, Rojas E, Nunez L, Kong Y, Gies DR, Stitt TN, Ip NY, Yancopoulos GD (1993) Alternative forms of rat TrkC with different functional capabilities. Neuron 10:963-974.
Verhaagen J, Ocstreicher AB, Gispen WH, Margolis FL (1989) The expression of the growth associated protein B50/GAP43 in the olfactory system of neonatal and adult rats. J Neurosci 9:683-691.

Vollrath M, Altmannsberger M, Weber K, Osborn M (1985) An ultrastructural and immunohistological study of the rat olfactory epithelium: unique properties of olfactory sensory cells. Differentiation 29:243-253.

Williams R, Rush RA (1988) Electron microscopic immunocytochemical localization of nerve growth factor in developing mouse olfactory neurons. Brain Res 463:21-27.

Wright EM, Vogel KS, Davies AM (1992) Neurotrophic factors promote the maturation of developing sensory neurons before they become dependent on these factors for survival. Neuron 9:139-150. 